\title{
Expression of heat shock protein 90 alpha

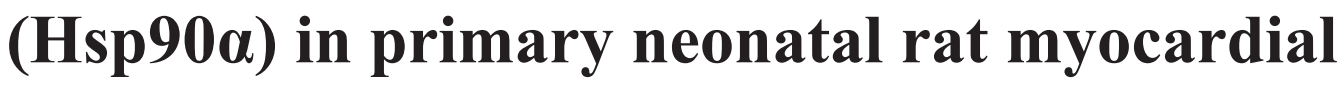 cells exposed to various periods of heat stress in vitro
}

\author{
A. Islam ${ }^{1}$, B. Rehana ${ }^{1}$, M. Zhang ${ }^{1,2}$, Z.J. Liu ${ }^{1,3}$, S. Tang ${ }^{1}$, J. Hartung ${ }^{4}$ and \\ E.D. Bao ${ }^{1}$ \\ ${ }^{1}$ College of Veterinary Medicine, Nanjing Agricultural University, \\ Weigang 1, Nanjing, China \\ ${ }^{2}$ College of Animal Science and Technology, Jinling Institute of Technology, \\ Nanjing, China \\ ${ }^{3}$ College of Animal Science and Technology, \\ Henan University of Science and Technology, Luoyang, China \\ ${ }^{4}$ Institute for Animal Hygiene, Animal Welfare and Farm Animal Behaviour, \\ University of Veterinary Medicine Hannover, Foundation, Hannover, Germany
}

Corresponding author: E.D. Bao

E-mail: b_endong@njau.edu.cn

Genet. Mol. Res. 13 (2): 2806-2816 (2014)

Received May 27, 2013

Accepted September 18, 2013

Published April 14, 2014

DOI http://dx.doi.org/10.4238/2014.April.14.9

ABSTRACT. The objective of this study was to investigate the mechanism of heat shock protein 90 alpha $(\mathrm{Hsp} 90 \alpha)$ protection against heart damage resulting from heat stress by detecting Hsp90 $\alpha$ mRNA, Hsp90 $\alpha$ protein, protein localization, and cell damage in primary myocardial cells of neonatal rats in response to heat stress in vitro. The cells were heat-stressed at $42^{\circ} \mathrm{C}$ in an incubator with $95 \%$ air and $5 \% \mathrm{CO}_{2}$ for different periods. Levels of Hsp90 $\alpha$, protein localization, enzymes, and cytopathological lesions were detected using Western blot, immunocytochemistry enzymatic assays, and cytopathological techniques. Aspartate aminotransferase, lactate 
dehydrogenase, and creatine kinase enzyme levels were elevated during heat stress, and acute cellular lesions that were characterized by vacuolar degeneration and necrosis were observed. Hsp90 $\alpha$ levels decreased between 10 and $60 \mathrm{~min}$ of heat stress and increased after 360 and $480 \mathrm{~min}$, while Hsp90 $\alpha$ mRNA decreased after $360 \mathrm{~min}$. These results indicate that heat stress might induce irreversible damage in certain myocardial cells. The elevated Hsp90 $\alpha$ level at the end of heat stress and its positive signal in the cytoplasm of myocardial cells after heat stress could be associated with its protective role. Additionally, the consumption of Hsp90 $\alpha$ exceeded its production in the first period of treatment.

Key words: Heat stress; Heat shock protein 90 alpha (Hsp90 $\alpha$ ); Creatine kinase; Primary myocardial cells

\section{INTRODUCTION}

Heat shock proteins (HSPs) are normally present in mammalian cells and are activated by physical, chemical, and biological stress (Staib et al., 2007). Heat stress is a major aspect that affects mammals, and its effect on HSPs needs to be investigated. HSPs are classified by their molecular weight, which ranges from 10 to $150 \mathrm{kDa}$ (Benjamin and McMillan, 1998). HSPs are known to act as molecular chaperones in protein assembly and disassembly (Haslbeck et al., 2005), protein folding and unfolding (Zietkiewicz et al., 2004), protein translocation (Ryan and Pfanner, 2001), and the refolding of damaged proteins (Marques et al., 2006). HSPs support the folding of proteins into biologically active conformations (Schwarz et al., 1996) and can bind proteins that are in a non-native conformation because of environmental stress-induced protein denaturation. These molecules minimize the aggregation of non-native proteins and target damaged proteins for hydrolysis and removal from the cell (Hofmann et al., 1999), suggesting that HSPs can protect and repair cells and tissues. The over-expression of one or more HSPs confers protection against stress (Luh et al., 2007) because they regulate apoptosis and cell death resulting from stress. Furthermore, HSPs can inhibit or aid the apoptotic mechanism through their chaperone functions by affecting protein folding, ubiquitin degradation, and protein translocation pathways (Takayama et al., 2003).

Hsp90 $(83-99 \mathrm{kDa})$ is the most highly expressed stress protein in the cytoplasm, nucleus, and endoplasmic reticulum of eukaryotic cells (Lindquist and Craig, 1988; Welch, 1990). The two major isoforms of Hsp90, namely, Hsp90 $\alpha$ and Hsp90ß, are highly expressed at basal levels, and various stresses increase the expression of both forms to different degrees (Romanucci et al., 2006). Hsp90 $\alpha$ ( $86 \mathrm{kDa}$ ) is a highly conserved cytosolic protein (Csermely et al., 1998) whose levels increase in response to heat stress and other environmental conditions (Bagatell et al., 2000). It maintains cell structures and supports maturation (Maloney and Workman, 2002; Neckers, 2002), and, because it is highly conserved and inducible, it is a good mediator of cellular stress (Prohaszka and Fust, 2004). As a molecular chaperone, Hsp90 $\alpha$ is involved in regulating productive interactions of steroids with their cellular receptors, prevents protein denaturation, and refolds proteins into their proper structures with assistance from the prolyl isomerase family. The induction of Hsp90 $\alpha$ in response to environmental, physical, and chemical stresses is therefore essential for the maintenance of cellular integrity and survival of the organisms (Bose et al., 1996; Ekambaram et al., 2008). Hsp90 also crosslinks with actin filaments in a $\mathrm{Ca}^{2+}$ - and ATP-dependent manner (Nishida et al., 1986), which, in turn, might 
help modulate the cytoskeletal dynamics in stressed cells and for myocardial protection.

Heat stress can cause damage to different organs, including the heart (Yu et al., 2008; Yan et al., 2009), while HSPs can protect the myocardium from the damaging effects of ischemia and reperfusion. A shortage of HSPs associated with lesions in the myocardium may cause electromechanical dissociation, which can result in acute heart failure and death, as observed under poor environmental and management conditions, such as stressful transport (Luh et al., 2007). Although Hsp90 was able to protect cultured primary cardiac cells (Cumming et al., 1996), little information is available to support a specific role for Hsp90 $\alpha$ and its expression in response to heat stress in primary cultures of cardiac myocytes in vitro. Although it has been demonstrated that a lack of HSP in cardiac cells results in acute heart failure (Amrani et al., 1993), the mechanisms by which Hsp90 $\alpha$ offers protection against this remain unclear. The aim of this study was to detect the expression and localization of $\mathrm{Hsp} 90 \alpha$ in primary myocardial cells from neonatal rats and to correlate this with heart tissue damage resulting from exposure to heat stress.

\section{MATERIAL AND METHODS}

\section{Cell culture and experimental treatment}

Primary myocardial cells from neonatal rats were obtained from Fu Meng Biological Technology Ltd., Shanghai, China. The experiments were also conducted in the same laboratory. Cells were grown on $35 \mathrm{~cm}^{2}$ polylysine-coated coverslips at a density of $2-8 \times 10^{4}$ cells/ plate, and the cultures were incubated at $37^{\circ} \mathrm{C}$ in a humidified atmosphere of $5 \% \mathrm{CO}_{2}$ and $95 \%$ air for $72 \mathrm{~h}$ to allow the cells to adapt. When a minimum of $85 \%$ of the cells in a culture were alive, viable, and beating after this period, the culture was divided into 9 groups: the control group and 8 groups exposed to heat stress for 10, 20, 40, 60, 120, 240, 360, and 480 min by incubation in a $42^{\circ} \mathrm{C}$ incubator with a humidified atmosphere of $5 \% \mathrm{CO}_{2}$ and $95 \%$ air. The ambient temperature of the control group was maintained at $37^{\circ} \mathrm{C}$.

\section{Determination of lactate dehydrogenase (LDH), aspartate aminotransferase (AST), and creatine kinase (CK) activities}

The supernatants of the cell cultures were collected from each plate, transferred into centrifuge tubes, and stored at $-80^{\circ} \mathrm{C}$. The activities of AST, CK, and LDH were measured according to the instructions given in the commercial kits (A020-1, C010, and A032, respectively, Nanjing Jiancheng Biochemical Reagent Co., China).

\section{Immunocytochemical detection of Hsp90 $\alpha$}

After collecting the supernatants, the cultures were fixed with $4 \%$ paraformaldehyde for $30 \mathrm{~min}$ at room temperature (RT) and permeabilized with $0.4 \%$ Triton X-100 in phosphatebuffered saline (PBS). After blocking with 5\% skim milk in PBS for $1 \mathrm{~h}$, the cells were overlaid with anti-rat Hsp90 $\alpha$ monoclonal antibody (ab79849, Abcam, USA) at a dilution of 1:200 in a moist chamber at $37^{\circ} \mathrm{C}$ for $1 \mathrm{~h}$. After washing 3 times with PBS, the cells were incubated with rhodamine red-conjugated goat anti-mouse IgG antibody (BA1031, Boster, China) at a $1: 100$ dilution at $37^{\circ} \mathrm{C}$ for $1 \mathrm{~h}$ and then were washed again with PBS before counterstaining with 4',6-diamidino-2-phenylindole (DAPI) solution and being observed with an immunofluo- 
rescence microscope (Beckman, USA).

\section{Detection of $h s p 90 \alpha \mathrm{mRNA}$ by fluorescence quantitative real-time polymerase chain reaction (qRT-PCR)}

\section{Isolation of total RNA and reverse transcription}

After the heat exposure at $42^{\circ} \mathrm{C}$, the cultures were washed with PBS, and total RNA was isolated using TRIZOL (Invitrogen, USA) according to manufacturer instructions. The concentration of RNA was determined using a spectrophotometer (Mx3000P, USA) at 260 $\mathrm{nm}$. Serial dilutions of RNA were prepared with ribonuclease-free water, and $2 \mu \mathrm{g}$ each sample was synthesized into DNA using the Transcript M-MLV kit (AM1710, Invitrogen, USA) following manufacturer protocol and stored at $-80^{\circ} \mathrm{C}$.

\section{Primer design for hsp90a $m R N A$}

Primer sets were specifically designed to anneal to each target mRNA. The sequences of $h s p 90 \alpha$ mRNA and $\beta$-actin mRNA were obtained from the National Center for Biotechnology Information (NCBI) GenBank database (accessions NC_005105.2 and NC_005111.2, respectively). Using these sequences, primers were designed for $h s p 90 \alpha$ and $\beta$-actin (Table 1) by the Primer Premier 5.0 software for real-time reverse transcription-PCR (RT-PCR) amplification.

Table 1. Primers for real-time RT-PCR amplification.
\begin{tabular}{lcll}
\hline Gene & Amplicon size (bp) & Sense primer (5'-3') & Antisense primer (5'-3') \\
\hline hsp $90 \alpha$ mRNA & 214 & CCCGGTGCGGTTAGTCACGT & TCCAGAGCGTCTGAGGAGTTGGA \\
$\beta$-actin $m R N A$ & 143 & CCCATCTATGAGGGTTCA & TCACGCACGATTTCC \\
\hline
\end{tabular}

\section{qRT-PCR}

Each DNA sample ( $2 \mu \mathrm{L}, 25$ times dilution) was suspended in $2 \mathrm{X}$ SYBR Premix Ex $\operatorname{Taq}^{\mathrm{TM}}$ (15218-019, Invitrogen, USA) with primers (25 pmol each of sense and anti-sense primer), and double-distilled water to a total volume of $25 \mu \mathrm{L}$. Quantitative PCR was performed using an ABI 7300 real-time PCR thermocycler (Applied Biosystems, USA). The thermal profile was $95^{\circ} \mathrm{C}$ for $3 \mathrm{~min}$ for enzyme activation, followed by denaturing at $95^{\circ} \mathrm{C}$ for $5 \mathrm{~s}$ and annealing and elongation at $52^{\circ} \mathrm{C}$ for $30 \mathrm{~s}$ for a total of 45 cycles. For each run, a negative control without DNA was performed. A 2-fold dilution series of the template was used in the qRT-PCR reactions. The $h s p 90 \alpha$ mRNA in all samples was normalized using the following formula: Relative quantity of $h s p 90 \alpha$ mRNA $=2^{-\Delta \Delta \mathrm{Ct}} \Delta \Delta \mathrm{Ct}=\left(\mathrm{Ct}_{h s p 90 \alpha \mathrm{mRNA}}-\mathrm{Ct}_{\beta \text {-actin }}\right)$ control group - $\left(\mathrm{Ct}_{h s p 90 \alpha \mathrm{mRNA}}-\mathrm{Ct}_{\beta \text {-actin }}\right)$ test group.

\section{Western blot analysis}

After treatment at $42^{\circ} \mathrm{C}$, cardiac muscle cells were washed with PBS and lysed with sodium dodecyl sulfate (SDS)-polyacrylamide gel Laemmli sample buffer. Cell lysates were collected and boiled for $5 \mathrm{~min}$. Equal amounts of protein $(10 \mu \mathrm{g})$ were subjected to $10 \%$ SDS-polyacrylamide gel electrophoresis and transferred onto a nitrocellulose membrane by electrotransfer. The membrane was blocked with 5\% non-fat milk in Tris-buffered saline (20 
$\mathrm{mM}$ Tris-HCl, $\mathrm{pH}$ 7.6, $137 \mathrm{mM} \mathrm{NaCl}$ ) containing 0.1\% Tween-20 (TTBS) for $1 \mathrm{~h}$ at RT and incubated with anti-rat Hsp90 $\alpha$ monoclonal antibody (ab79849, Abcam, USA) for $16 \mathrm{~h}$ at $4^{\circ} \mathrm{C}$. After washing with TTBS, the membrane was further incubated with horseradish peroxidaseconjugated goat anti-mouse IgG antibody (ab6789, Abcam, USA) for $1 \mathrm{~h}$ at RT. The antibodyantigen complexes were detected using Western blotting luminal reagent. The bands on the developed film were quantified with the Quantity One v.4.6.2 software (Bio-Rad, USA). The density of each band was normalized to that of $\beta$-actin.

\section{Statistical analysis}

All data were analyzed by one-way analysis of variance (ANOVA) using the Statistical Package for Social Sciences (SPSS). Where significant differences existed, Duncan's multiple range test was used to compare the means. Differences are reported as significant at $\mathrm{P}<0.05$. All experiments were repeated in triplicate.

\section{RESULTS}

\section{Enzyme levels of LDH, AST, and CK}

As illustrated in Figure 1, AST activity levels increased significantly during the course of heat exposure $(\mathrm{P}<0.01)$ compared to the control. The levels of LDH increased at $20 \mathrm{~min}$ $(\mathrm{P}<0.05)$ and then decreased quickly after $40 \mathrm{~min}$ of heat stress. The LDH activity remained higher than that of the control cells, but the difference was not statistically significant. After $480 \mathrm{~min}$, the levels of LDH increased again to a significant level $(\mathrm{P}<0.05)$. The levels of CK also increased, but the change was only significant after 120 min of heat stress $(\mathrm{P}<0.05)$.

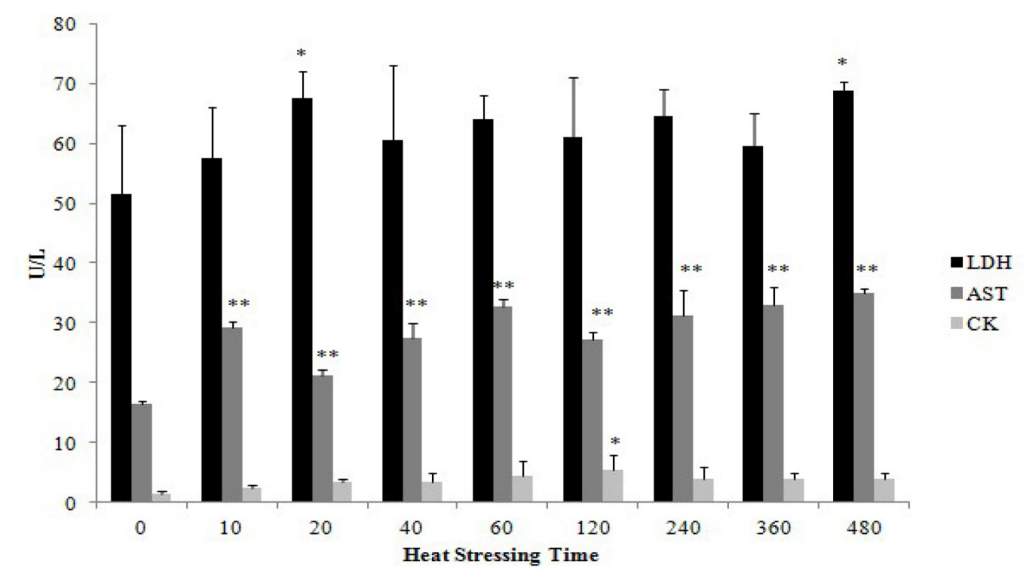

Figure 1. Activity levels of LDH, AST, and CK in primary rat neonatal myocardial cells (U/L). *P $<0.05 ; * * \mathrm{P}<$ 0.01 compared with the control group; values are indicated as means $\pm \mathrm{SD} ; \mathrm{N}=3$.

\section{Transcription levels of $h s p 90 \alpha$ mRNA in heat-stressed rat myocardial cells}

The $h s p 90 \alpha$ mRNA data for the rat myocardial cells after different periods of heat stress 
are displayed in Figure 2. The level of $h s p 90 \alpha$ mRNA increased after 10 min of heat stress $(\mathrm{P}$ $<0.05)$ and reached the highest level after $240 \mathrm{~min}(\mathrm{P}<0.01)$. All other periods of heat stress resulted in significantly $(\mathrm{P}<0.01)$ higher levels of $h s p 90 \alpha$ mRNA transcription than the control.

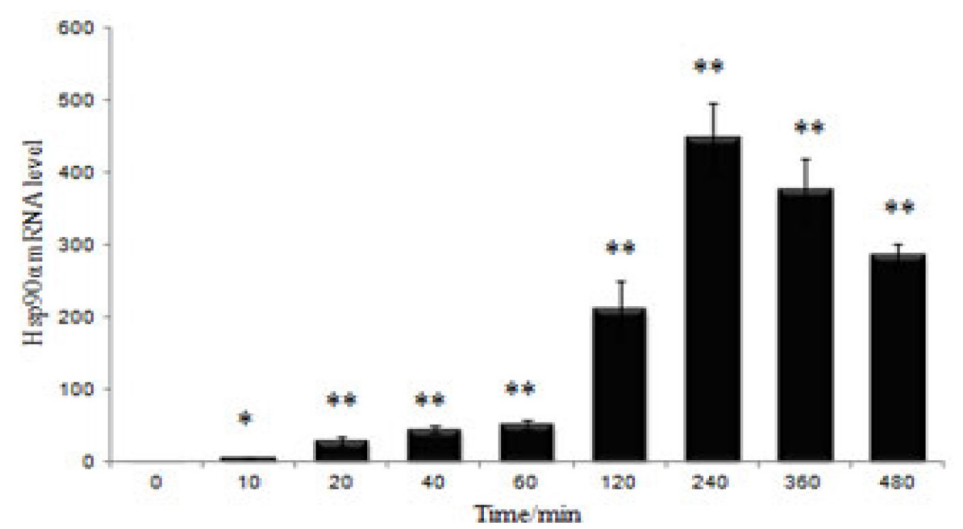

Figure 2. Transcription levels of $h s p 90 \alpha$ mRNA in primary rat neonatal myocardial cells exposed to various lengths of heat stress. ${ }^{*} \mathrm{P}<0.05 ; * * \mathrm{P}<0.01$ compared with the control group; values are reported as the means $\pm \mathrm{SD} ; \mathrm{N}=3$.

\section{Expression levels of Hsp90 $\alpha$ in heat-stressed rat myocardial cells}

The Hsp90 $\alpha$ expression levels that were detected in the rat myocardial cells after different periods of heat stress are shown in Figure 3. Hsp90 $\alpha$ expression decreased significantly $(\mathrm{P}<0.01)$ within the first $10 \mathrm{~min}$ of heat stress. The expression level stayed almost constant until $60 \mathrm{~min}$ of treatment. After $120 \mathrm{~min}$, the level returned to the control level. During treatments longer than $2 \mathrm{~h}, \mathrm{Hsp} 90 \alpha$ expression increased and reached the highest level after $360 \mathrm{~min}$.

(A)
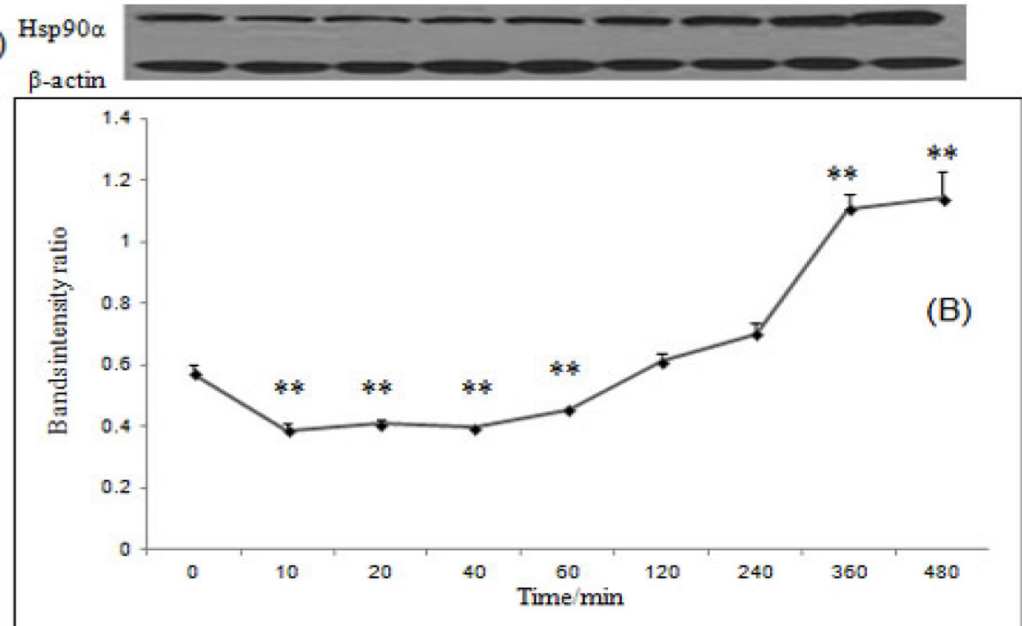

Figure 3. Levels of Hsp90 $\alpha$ expression in primary rat neonatal myocardial cells exposed to various lengths of heat stress. ${ }^{*} \mathrm{P}<0.05 ; * * \mathrm{P}<0.01$ compared with the control group; values are reported as the means $\pm \mathrm{SD} ; \mathrm{N}=3$. 


\section{Immunocytochemical observations}

Immunocytochemical staining for Hsp90 $\alpha$ in primary rat myocardial cells is shown in Figure 4. Positive staining for Hsp90 $\alpha$ was detected in both the nucleus and cytoplasm of the myocardial cells. However, the positive staining in the cytoplasm was stronger than that in the nucleus.

A
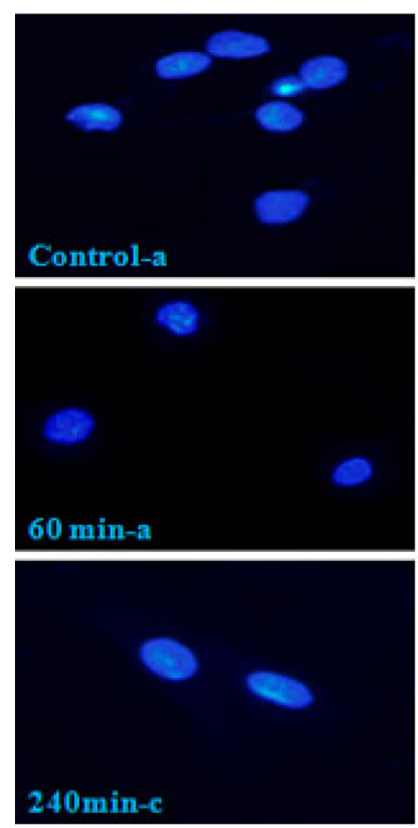

B
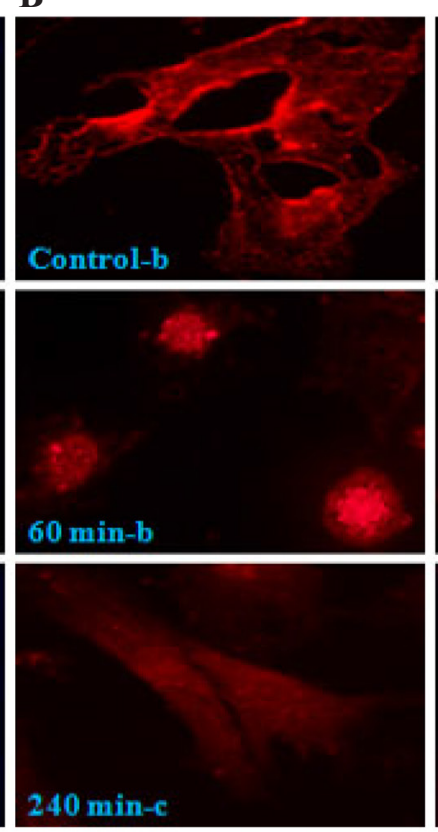

C
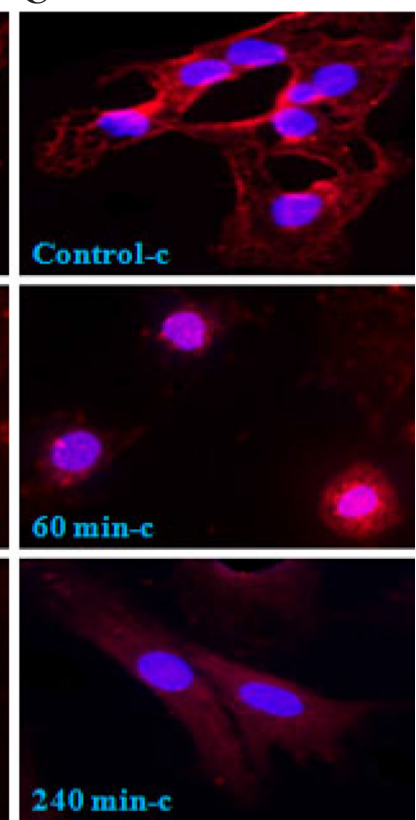

Figure 4. Representative photomicrographs of cardiomyocytes. Immunocytochemical detection of Hsp90a distribution in primary rat neonatal myocardial cells before and after heat stress. Positive signals for Hsp90 $\alpha$ in the nucleus and cytoplasm of non heat stressed myocardial cells. The positive staining in the cytoplasm is stronger than in the nucleus. A. DAPI; B. Hsp90 $\alpha$; C. Merge.

\section{DISCUSSION}

Heat stress is known to damage the integrity of various tissues, including myocardial cells, and it induces the expression of HSPs (Yu et al., 2008; Yan et al., 2009). Among the key indicators of tissue damage caused by heat stress, the activity of AST, CK, and LDH are well recognized (Li et al., 2008). In pigs, a relationship between environmental stressors including transport, the expression of Hsp90, and myocardial cell damage has been postulated (Yue et al., 2010) with heat stress being applied as a defined stressor. A gradual change in LDH, AST, and $\mathrm{CK}$ takes place when the ambient temperature is increased from 37 to $42^{\circ} \mathrm{C}$, and the presence of CK and AST in the blood serum is often associated with muscle damage (Fabrega et al., 2002).

The serum activity levels of the AST, LDH, and CK increased after rats were exposed to 6 and $24 \mathrm{~h}$ heat stress (Manjoo et al., 1985). This was also evident in our study: the levels of LDH, AST, and CK increased over the course of heat stress. CK is found in cardiac muscle 
fibers, increases rapidly after intense physical exertion (Britton et al., 1980), and is the most sensitive parameter of tissue damage (Manjoo et al., 1985). We saw a gradual increase in CK levels during the course of heat stress, and CK levels were the highest at $120 \mathrm{~min}$ of heat stress. These results agree with those of earlier studies demonstrating that plasma CK concentrations increased in heat stressed broilers in vivo during the period of heat exposure time and reached a peak level after $10 \mathrm{~h}$ of heat stress (Sun et al., 2007; Yu et al., 2008). In contrast, another group reported that $\mathrm{CK}$ was significantly reduced in the hearts of rats exposed to $15 \mathrm{~min}$ of heat shock after 5 minutes of reperfusion (Currie et al., 1988). In this study, the levels of all 3 tested enzymes were elevated with the application of heat stress, confirming that heat stress induces damage in myocardial cells in vitro.

Temperatures from 3 to $5^{\circ} \mathrm{C}$ cause cells from all organisms to initiate the expression of HSPs (Locke and Noble, 1995). However, our results demonstrated that Hsp90 $\alpha$ protein levels decrease significantly during the first hour of heat stress treatment, while the enzyme activities and cell damage indicators were elevated, as exemplified by the CK enzyme. This indicates that heat stress induces the irreversible damage and death of certain myocardial cells because of the decrease in Hsp90 $\alpha$ levels in the myocardial cells, and it suggests that the consumption of Hsp90 $\alpha$ by the cells exceeded its production at the beginning of heat stress in myocardial cells. HSPs can act as protective responses to external stressors, thereby maintaining the cell structure and preventing protein aggregation and denaturation (Marruchella et al., 2004). Several studies have demonstrated the cytoprotective activity of HSPs against ischemia and reperfusion-associated damage in the heart (Seok et al., 2007). Therefore, the reduced HSP levels in the myocardium may lead to acute heart failure, while accumulating HSPs in cardiac cells enhances myocardial resistance to ischemia/reperfusion injury and improves postischemic recovery of cardiac function (Amrani et al., 1993). Hsp90 has the ability to regulate the activity of specific proteins, such as enzyme and hormone receptors, but it regulates the transcription of other HSPs to an even greater extent by its association with transcription factors that modulate the transcriptional activity and expression of other HSPs (Nadeau et al., 1993). A significant increase in Hsp90 $\alpha$ in primary cardiac muscle cells after 360 min of heat stress was recorded, which contrasted with observations made during the first hour. Over the same time period, the CK enzyme associated with heart disease also demonstrated decreased activity levels. Although the stress damage of myocardial cells still existed in the sustaining hyperthermia situation, these results showed that Hsp90 $\alpha$ started to increase after 120 min and reached significantly high levels after $360 \mathrm{~min}$ of heat stress, while CK started to decrease. The over-expression of Hsp90 can protect either cultured primary cardiac cells (Cumming et al., 1996) or H9c2 cells against heat stress (Heads et al., 1995). However, the cytoprotective activity of Hsp90a was delayed in its action against heat stress at the beginning of the heat treatment, which could be attributed to the consumption of Hsp90 $\alpha$ exceeding its production. This was reversed after $120 \mathrm{~min}$, when Hsp90 $\alpha$ levels started to increase and reached a peak after $360 \mathrm{~min}$ of heat stress.

The expression of Hsp90 $\alpha$ in both the cytoplasm and nucleus of the myocardial cells may have a functional significance for the refolding of denatured proteins caused by heat stress. As revealed by immunocytochemical results, Hsp90 $\alpha$ expressed positive granules in the primary muscle cells that were exposed to $37^{\circ} \mathrm{C}$, while the expression of Hsp90 $\alpha$ was increased after 60 and 240 min of heat stress, which was consistent with previous findings that Hsp90 $\alpha$ is a constitutively expressed cytosolic protein under physiological conditions and that its levels increase in response to heat stress (Csermely et al., 1998). The role of Hsp90 is to protect the cytoskeleton. Hsp90 associated with actin microfilaments and tubulin microtubules, which 
are major constituents of the cell cytoskeleton, and influenced microfilament organization. Hsp90 possesses an ATP-binding site and low ATPase activity and can bind unoccupied steroid hormone receptors (Kellermayer and Csermely, 1995). Hsp90 has been characterized as a molecular chaperone that is able to keep proteins in a folding-competent state. It has enhanced chaperone activity in an oligomeric form at high temperature. Taken together, Hsp $90 \alpha$ may have a significant role in the survival and structural integrity of the cell after stress and protection of cardiac muscle cells. Cellular damage and ATP depletion in stressed cells that are induced by hyperthermia leads to protein aggregation and affects cytoskeletal structures (Kabakov and Gabai, 1997), but they may be overcome by inducting Hsp90 $\alpha$. Therefore, Hsp90 $\alpha$ seems to contribute to the stabilization of the intracellular protein structure by refolding denatured proteins and steroid activation (Ekambaram et al., 2008). However, Hsp90 $\alpha$ expression in response to high temperature and its association with myocardial cell protection against heat stress still needs further investigation. The heat stress model that was used in this experiment may be a helpful tool to further elucidate the relationship between HSP expression and tissue damage in the heart and other organs.

The levels of hsp 90 mRNA increased immediately and steadily from the beginning of heat stress treatment, while the level of Hsp90 $\alpha$ protein expression decreased continuously until $60 \mathrm{~min}$ of heat stress. $h s p 90 \alpha \mathrm{mRNA}$ showed a significant and continuous induction from the start of heat stress and reached the highest level at $240 \mathrm{~min}$ of heat stress in vitro; however, the obvious elevation of Hsp90 $\alpha$ protein occurred in the primary myocardial cells after $360 \mathrm{~min}$ of heat stress. The possible explanation for this may be that heat stress overwhelmed the repair mechanism of the myocardial cells. The results imply that the consumption of Hsp90 $\alpha$ exceeded its production at the beginning of treatment, and the irreversible damages were induced by the decrease of protective Hsp90 $\alpha$ protein in the myocardial cells. The expression of Hsp90 $\alpha$ and its corresponding mRNA therefore depends on a number of unknown factors related to the trigger that is applied to elicit Hsp90 $\alpha$ synthesis. Several studies have documented the protective role of HSPs against stress-induced myocardial damage. Myocytes express high levels of Hsp90 $\beta$, which reflects significant preservation against heat stress (Heads et al., 1995). In addition, the low correlation between the level of $h s p 90 \alpha$ mRNA and the level of Hsp90 $\alpha$ protein may refer to the complicated post-transcriptional mechanisms that are involved in turning mRNA into protein. These results are supported by earlier reports that demonstrate the reasons for the poor correlation between the mRNA and protein levels. For example, many complicated post-transcriptional mechanisms that are involved in turning mRNA into protein are not yet sufficiently well-defined to allow the computation of protein concentrations from mRNA, and proteins may differ substantially in their in vivo half-lives (Baldi and Long, 2001; Ostlund and Sonnhammer, 2012).

\section{ACKNOWLEDGMENTS}

Research supported by the National Key Basic Research Program of China ("973" Program) (\#2014CB138502), the National Natural Science Foundation of China (\#31372403), the National Department Public Benefit Research Foundation (Agriculture) (\#20100306011), the Priority Academic Program Development of Jiangsu Higher Education Institutions (PAPD), Graduate research and innovation projects in Jiangsu Province and the Sino-German Agricultural Cooperation Project of the Federal Ministry of Food, Agriculture and Consumer Production, Berlin, Germany. 


\section{REFERENCES}

Amrani M, Allen NJ, O'Shea J, Corbett J, et al. (1993). Role of catalase and heat shock protein on recovery of cardiac endothelial and mechanical function after ischemia. Cardioscience 4: 193-198.

Bagatell R, Paine-Murrieta GD, Taylor CW, Pulcini EJ, et al. (2000). Induction of a heat shock factor 1-dependent stress response alters the cytotoxic activity of hsp90-binding agents. Clin. Cancer Res. 6: 3312-3318.

Baldi P and Long AD (2001). A Bayesian framework for the analysis of microarray expression data: regularized $t$-test and statistical inferences of gene changes. Bioinformatics 17: 509-519.

Benjamin IJ and McMillan DR (1998). Stress (heat shock) proteins: molecular chaperones in cardiovascular biology and disease. Circ. Res. 83: 117-132.

Bose S, Weikl T, Bugl H and Buchner J (1996). Chaperone function of Hsp90-associated proteins. Science 274: 1715-1717.

Britton CV, Hernandez A and Roberts R (1980). Plasma creatine kinase isoenzyme determinations in infants and children. Characterization in normal patients and after cardiac catheterization and surgery. Chest 77: 758-760.

Csermely P, Schnaider T, Soti C, Prohaszka Z, et al. (1998). The 90-kDa molecular chaperone family: structure, function, and clinical applications. A comprehensive review. Pharmacol. Ther. 79: 129-168.

Cumming DV, Heads RJ, Watson A, Latchman DS, et al. (1996). Differential protection of primary rat cardiocytes by transfection of specific heat stress proteins. J. Mol. Cell. Cardiol. 28: 2343-2349.

Currie RW, Karmazyn M, Kloc M and Mailer K (1988). Heat-shock response is associated with enhanced postischemic ventricular recovery. Circ. Res. 63: 543-549.

Ekambaram P, Munuswamy UR and Vijaya GB (2008). Differential HSP90 $\alpha$ expression in fish hepatocytes from polluted estuary during summer. Fish. Sci. 74: 1118-1126.

Fabrega E, Manteca X, Font J, Gispert M, et al. (2002). Effects of halothane gene and pre-slaughter treatment on meat quality and welfare from two pig crosses. Meat. Sci. 62: 463-472.

Haslbeck M, Miess A, Stromer T, Walter S, et al. (2005). Disassembling protein aggregates in the yeast cytosol. The cooperation of Hsp26 with Ssa1 and Hsp104. J. Biol. Chem. 280: 23861-23868.

Heads RJ, Yellon DM and Latchman DS (1995). Differential cytoprotection against heat stress or hypoxia following expression of specific stress protein genes in myogenic cells. J. Mol. Cell. Cardiol. 27: 1669-1678.

Hofmann F, Lacinova L and Klugbauer N (1999). Voltage-dependent calcium channels: from structure to function. Rev. Physiol. Biochem. Pharmacol. 139: 33-87.

Kabakov AE and Gabai VL (1997). Heat shock proteins and cytoprotection: ATP-deprived mammalian cells. RG Landes Co, Austin.

Kellermayer MS and Csermely P (1995). ATP induces dissociation of the $90 \mathrm{kDa}$ heat shock protein (hsp90) from F-actin: interference with the binding of heavy meromyosin. Biochem. Biophys. Res. Commun. 211: 166-174.

Li LA, Xia D, Bao ED, Wei S, et al. (2008). Erhualian and Pietrain pigs exhibit distinct behavioral, endocrine and biochemical responses during transport. Livest. Sci. 113: 169-177.

Lindquist S and Craig EA (1988). The heat-shock proteins. Annu. Rev. Genet. 22: 631-677.

Locke M and Noble EG (1995). Stress proteins: the exercise response. Can. J. Appl. Physiol. 20: 155-167.

Luh SP, Kuo PH, Kuo TF, Tsai TP, et al. (2007). Effects of thermal preconditioning on the ischemia-reperfusion-induced acute lung injury in minipigs. Shock 28: 615-622.

Maloney A and Workman P (2002). HSP90 as a new therapeutic target for cancer therapy: the story unfolds. Expert. Opin. Biol. Ther. 2: 3-24.

Manjoo M, Burger FJ and Kielblock AJ (1985). A relationship between heat load and plasma enzyme concentration. $J$. Therm. Biol. 10: 221-225.

Marques C, Guo W, Pereira P, Taylor A, et al. (2006). The triage of damaged proteins: degradation by the ubiquitinproteasome pathway or repair by molecular chaperones. FASEB J. 20: 741-743.

Marruchella G, Di LM, Di GG, Romanucci M, et al. (2004). Heat shock proteins (HSPs) 27, 72 and 73 in normal and preulcerative mucosa of the gastric pars oesophagea in swine. J. Comp. Pathol. 131: 10-17.

Nadeau K, Das A and Walsh CT (1993). Hsp90 chaperonins possess ATPase activity and bind heat shock transcription factors and peptidyl prolyl isomerases. J. Biol. Chem. 268: 1479-1487.

Neckers L (2002). Hsp90 inhibitors as novel cancer chemotherapeutic agents. Trends Mol. Med. 8: S55-S61.

Nishida E, Koyasu S, Sakai H and Yahara I (1986). Calmodulin-regulated binding of the 90-kDa heat shock protein to actin filaments. J. Biol. Chem. 261: 16033-16036.

Ostlund G and Sonnhammer EL (2012). Quality criteria for finding genes with high mRNA-protein expression correlation and coexpression correlation. Gene 497: 228-236.

Prohaszka Z and Fust G (2004). Immunological aspects of heat-shock proteins-the optimum stress of life. Mol. Immunol. 41: 29-44.

Genetics and Molecular Research 13 (2): 2806-2816 (2014)

CFUNPEC-RP www.funpecrp.com.br 
Romanucci M, Marinelli A, Sarli G and Della SL (2006). Heat shock protein expression in canine malignant mammary tumours. BMC Cancer 6: 171.

Ryan MT and Pfanner N (2001). Hsp70 proteins in protein translocation. Adv. Protein Chem. 59: 223-242.

Schwarz E, Lilie H and Rudolph R (1996). The effect of molecular chaperones on in vivo and in vitro folding processes. Biol. Chem. 377: 411-416.

Seok SH, Baek MW, Lee HY, Kim DJ, et al. (2007). Arsenite-induced apoptosis is prevented by antioxidants in zebrafish liver cell line. Toxicol. In Vitro 21: 870-877.

Staib JL, Quindry JC, French JP, Criswell DS, et al. (2007). Increased temperature, not cardiac load, activates heat shock transcription factor 1 and heat shock protein 72 expression in the heart. Am. J. Physiol. Regul. Integr. Comp. Physiol. 292: R432-R439.

Sun PM, Liu YT, Zhao YG, Bao ED, et al. (2007). Relationship between heart damages and HSPs mRNA in persistent heat stressed broilers. Agr. Sci. 2: 227-233.

Takayama S, Reed JC and Homma S (2003). Heat-shock proteins as regulators of apoptosis. Oncogene 22: 9041-9047.

Welch WJ (1990). The Mammalian Stress Response: Cell Physiology and Biochemstry of Stress Proteins. In: Stress Proteins in Biology and Medicine (Morimoto RI, Tissieres A and Georgeopoulos C, eds.). Cold Spring Harbor Laboratory Press, New York, 223-278.

Yan J, Bao E and Yu J (2009). Heat shock protein 60 expression in heart, liver and kidney of broilers exposed to high temperature. Res. Vet. Sci. 86: 533-538.

Yu J, Bao E, Yan J and Lei L (2008). Expression and localization of Hsps in the heart and blood vessel of heat-stressed broilers. Cell Stress Chaperones 13: 327-335.

Yue Z, Hao Q, Tang S, Bao E, et al. (2010). Variation in Hsp90, HSF-1, and hsp 90 mRNA expression in tissues of pigs exposed to different durations of transport. Livest. Sci. 129: 141-145.

Zietkiewicz S, Krzewska J and Liberek K (2004). Successive and synergistic action of the Hsp70 and Hsp100 chaperones in protein disaggregation. J. Biol. Chem. 279: 44376-44383. 